\title{
Book Review: William Burroughs and neuropharmacology
}

Mentored by a madman

Peter A. Kempster

Neurology ${ }^{\circledR}$ 2018;91:e1455-e1456. doi:10.1212/WNL.0000000000006307

The literary works of William S. Burroughs (1914-1997) mirrored his lifestyle-countercultural, fragmentary, dedicated to fulfilment rather than control of impulses. He did not particularly like doctors and is a strange medical alterego. He was also a relentless explorer of the plant kingdom's chemical effects on the human brain through his addictive self-experiments. This is his chief role in Mentored by a Madman: The William Burroughs Experiment, Andrew Lees'1 artfully written neurologic memoir. It contains an eyewitness account of how various botanical substances, some of which Burroughs had tried on himself, were transformed into proven therapies for Parkinson disease.

Many of the most effective drugs to treat Parkinson disease have come, directly or indirectly, from the natural world. Tropane alkaloids, the first anticholinergic agents, were extracted from plants of the Solanaceae (nightshade) family. Levodopa was originally purified from broad beans. The dopamine receptor agonist apomorphine, almost as strong as levodopa, is found in water lilies. Ergoline derivatives from fungi gave rise to bromocriptine. Arvid Carlsson could not have made his discoveries in the 1950s about dopamine and the brain without observing the motor effects of the rauwolffia alkaloid reserpine.

At the same time as Carlsson was conducting his Nobel Prize-winning investigations, Burroughs, knowing nothing of dopamine or later research that would link it to risk-taking behavior, was using chemicals that altered his own cerebral dopaminergic balance. He took apomorphine to counter his heroin addiction and lauded its benefits in Naked Lunch. He dabbled with yagé, a hallucinatory brew of vines and leaves from the Amazonian rainforests, which turned out to have monoamine oxidase inhibitor properties. While pioneers of dopaminergic therapy such as Birkmayer, Hornykiewicz, and Barbeau had proceeded carefully from their neurochemical and pathologic understanding, some clinicians who made real differences in Parkinson disease had a little of Burroughs' adventurousness for just trying things. Robert Schwab saw apomorphine's antiparkinsonian effect in 1951, before anyone knew that dopamine was a neurotransmitter. George Cotzias made levodopa therapy a practical reality by persistence and belief.

Mentored by a Madman is the story of Andrew Lees' uncommon career in neurology, with his many scientific insights into movement disorders, his rapport with the past, and his talent for literary expression. Creative inspiration in neuroscience, Lees tells us, can come from unlikely sources - the notebooks of Richard Spruce, great 19th-century botanical explorer of Brazil; and Burroughs, the maverick interpreter of drug experience. There are parallels with the writings of Oliver Sacks, especially when patients enter the narrative. To a greater degree, though, this book inhabits the neurologist's inner world-observing, attending to detail, engaged in detective work.

Medicine is intertwined with 2 strands of thinking. One relies on a systematic application of its scientific principles. The other is intuitive, improvised, and imaginative. The first is the indispensable foundation of modern medical practice. Yet sometimes it fosters an excessive pride in its systems and processes, preferring uniformity to individuality. The second can be
Correspondence Dr. Kempster peter.kempster@ monashhealth.org

From the Neurosciences Department, Monash Medical Centre; and Department of Medicine, Monash University, Clayton, Australia.

Go to Neurology.org/N for full disclosures. Funding information and disclosures deemed relevant by the authors, if any, are provided at the end of the article. 
better understood by reading this book. Although Andrew Lees began his career a generation after the miraculous advent of levodopa, he channeled the spirit of those times into his clinical studies of Parkinson disease. His book chronicles the tail end of a heroic age in neuropharmacology. No one now relies on self-administration in research, and scientific journals would probably not publish the results if they did. But several figures who appear in Mentored by a Madman were heroes, and their kleos, a word subtly different from fame or glory, outlives them in the medications that we give our patients.

\section{Study funding}

No targeted funding reported.

\section{Disclosure}

P. Kempster reports no disclosures relevant to the manuscript. Go to Neurology.org/N for full disclosures.

\section{Reference}

1. Lees AJ. Mentored by a Madman: The William Burroughs Experiment. Honiton, UK: Notting Hill Editions; 2016. 


\section{Neurology}

\section{Book Review: William Burroughs and neuropharmacology: Mentored by a madman \\ Peter A. Kempster \\ Neurology 2018;91;e1455-e1456 \\ DOI 10.1212/WNL.0000000000006307}

This information is current as of October 8, 2018

$\begin{array}{ll}\begin{array}{l}\text { Updated Information \& } \\ \text { Services }\end{array} & \begin{array}{l}\text { including high resolution figures, can be found at: } \\ \text { http://n.neurology.org/content/91/15/e1455.full }\end{array} \\ \text { Permissions \& Licensing } & \begin{array}{l}\text { Information about reproducing this article in parts (figures,tables) or in } \\ \text { its entirety can be found online at: } \\ \text { http://www.neurology.org/about/about_the_journal\#permissions }\end{array} \\ \text { Reprints } & \begin{array}{l}\text { Information about ordering reprints can be found online: } \\ \text { http://n.neurology.org/subscribers/advertise }\end{array}\end{array}$

Neurology ${ }^{\circledR}$ is the official journal of the American Academy of Neurology. Published continuously since 1951, it is now a weekly with 48 issues per year. Copyright (O 2018 American Academy of Neurology. All rights reserved. Print ISSN: 0028-3878. Online ISSN: 1526-632X.

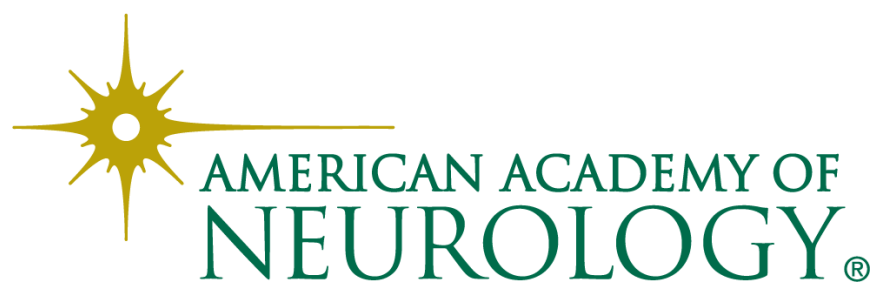

